\title{
THE EFFECT OF INSTITUTIONAL OWNERSHIP, DEBT COVENANT AND GROWTH OPPORTUNITY ON ACCOUNTING CONSERVATISM
}

\author{
Gracela Mayaniputri Tamur \\ Sarjanawiyata Tamansiswa University \\ E-mail: gracelamayani@gmail.com
}

\begin{tabular}{|c|c|}
\hline ARTICLE INFO & ABSTRACT \\
\hline $\begin{array}{l}\text { Received: } \\
\text { July, 24th } 2021 \\
\text { Revised: } \\
\text { August, } 16^{\text {th }} 2021 \\
\text { Approved: } \\
\text { August, 18 } \\
\text { th } 2021\end{array}$ & $\begin{array}{l}\text { This study aims to analyze the positive effect of institutional } \\
\text { ownership on accounting conservatism, analyze the negative } \\
\text { effect of debt covenants on accounting conservatism, and } \\
\text { analyze the effect of growth opportunities on accounting } \\
\text { conservatism. The population in this study are companies } \\
\text { listed in BUMN in the } 2016 \text { - } 2018 \text { financial year. All BUMN } \\
\text { companies listed on the IDX are used. Sampling was carried } \\
\text { out using purposive sampling method and had certain } \\
\text { criteria. The data collection method used is the } \\
\text { documentation method from electronic media. The data was } \\
\text { obtained from the internet (www.idx.go.id and company } \\
\text { website). Data analysis using multiple linear } \\
\text { regressionanalysis. The discussion that has been stated, the } \\
\text { following conclusions can be drawn; 1). Institutional } \\
\text { ownership structure has no effect on accounting } \\
\text { conservatism. 2). Debtcovenants have no effect } \\
\text { onbaccounting conservatism. 3). Gross opportunity has a } \\
\text { significant positive effect on accounting conservatism. }\end{array}$ \\
\hline KEYWORDS & $\begin{array}{l}\text { Accounting Conservatism, Institutional Ownership, Debt } \\
\text { Covenant and Growth Opportunities }\end{array}$ \\
\hline (c) (i) (2) & $\begin{array}{l}\text { This work is licensed under a Creative Com } \\
\text { Attribution-ShareAlike } 4.0 \text { International License }\end{array}$ \\
\hline
\end{tabular}

\section{INTRODUCTION}

Institutional ownership is the percentage of the number of shares owned by Gracela Mayaniputri Tamur. (2021) He Effect of Institutional Ownership, Debt Covenant and Growth Opportunity on Accounting Conservatism.

How to cite:

E-ISSN: Journal Eduvest. 1(8): 784-793

Published by: 


\section{Gracela Mayaniputri Tamur}

institutional parties from the total number of outstanding shares of the company (Mahariana \& Ramantha, 2014). Institutional parties include insurance companies (Ngadiman \& Puspitasari, 2017), banks, investment companies and ownership by other institutions (Yendrawati, 2015). Agency theory explains that there is an agency relationship between managers and principals (Ardiansyah, 2014), the proportion of share ownership by external parties of the company can affect the level of conservatism applied by the company in preparing its financial statements (Limantauw, 2012).

Institutional ownership has the ability to control management through an effective monitoring process (Siregar, 2017) so as to reduce management's actions to manage earnings and tend to ask management to apply conservative accounting (Oktomegah, 2012). (Rebecca \& Siregar, 2012) states that institutional investors have a fairly large equity investment so that institutional investors are encouraged to monitor the actions (Sembiring, 2017) and performance of managers more closely (Damayanti, Edy Sujana, Werastuti, \& SE, 2015).

Other supervision that can be carried out is by providing inputs as consideration for managers (Susanto, 2011) in running the business and through the General Meeting of Shareholders (GMS) (Rizkianti, 2017). The greater the institutional ownership of the shares (Putri \& Putra, 2017), the more effective the supervision will be because it can control the opportunistic behavior of managers and reduce agency costs (Pratiwi \& Yulianto, 2016). The size of the share ownership structure can affect the company's policy and decision making (Syadeli, 2013).

Institutional Ownership Ownership of public companies used to be seen as scattered among many shareholders (Fadillah, 2017), but in reality this is not entirely true today (Zaudah Cyly Arrum Dalu \& Mojibur Rohman, 2019), especially for countries other than the United States. According to Zhang in Tarjo (2017), companies outside the United States are generally controlled by large shareholders. Research conducted by La Porta et al. (2018), as well as Faccio and Lang (2017) find that ownership of public companies in almost all countries is concentrated, except in the United States, United Kingdom and Japan. Indonesia is included in the group of countries whose share ownership in public companies is concentrated. The main agency problem in companies with this concentration of ownership is the conflict between the controlling shareholder and the minority shareholder. When associated with this research, it can be described how institutional investors as the majority shareholder use their control to influence the company's accounting conservatism policy. In short, institutional ownership means share ownership by other institutions.

Institutional ownership is one of the tools that can be used to reduce agency conflict. Eriandani (2018) states that institutional investors usually control a large number of shares so that they can influence decision making. Through a large proportion of institutional ownership, owners can direct management actions to apply conservative accounting principles with the aim of avoiding opportunistic actions by management to manipulate company performance. Research conducted by Wardhani (2017) states that the greater the institutional ownership in the company's ownership structure, the more it encourages the use of conservative accounting principles as measured by accrual measures. Similar results were also obtained in a study conducted by Indrayati (2017), where he stated that institutional ownership has a positive and significant relationship to the level of accounting conservatism. (Ramadona, Tanjung, \& Rusli, 2016) states that the greater the institutional ownership, the greater the monitoring (monitoring) carried out on the company's management and the greater the demand for transparent information.

The principle of conservatism states that when choosing between 2 or more acceptable accounting techniques, it is preferable to choose the one that has the least 
impact on shareholder capital. Several things that affect conservatism, one of which is the ownership structure. The ownership structure gives a different meaning in terms of overseeing the running of the company. The ownership structure is the type of institution or company that holds the largest share in a company (Wahyudi and Pawestri, 2017) in (Sabrinna, 2018:15). Institutional ownership structure is the percentage of the number of shares owned by the company compared to the number of shares owned by external parties. The size of the share ownership structure can affect the company's policy and decision making (Deviyanti, 2018: 28).

Research conducted by Deviyanti (2018) which examines the factors that influence the application of conservatism in accounting using the dependent variable conservatism and the independent variables are managerial ownership structure, institutional ownership structure, public ownership structure, firm size, and leverage. The results show that managerial ownership structure, institutional ownership structure and public ownership structure have a significant and negative effect on conservatism. Meanwhile, firm size and leverage have no effect and are positive.

Another factor that influences conservatism is growth opportunities, growth or company growth is a reflection of the value of a company, which is related to the survival of the company (Evana, 2016:4). According to research by Resti (2016) which discusses the factors that influence accounting conservatism, it states that growth opportunities, litigation, taxes, debt contracts, ownership structure have a significant influence on conservatism. Meanwhile, according to Winelti, Elfiswendi, and Yeni (2016) who conducted research on the effect of institutional ownership, debt covenants and growth opportunities on accounting conservatism, the results showed that institutional ownership had a significant effect on conservatism while debt covenants and growth opportunities did not have a significant effect on conservatism. . Based on the factors mentioned above, the researcher uses institutional ownership structure, debt covenants and growth opportunities as factors that are thought to explain variations in the practice of accounting conservatism.

\section{RESEARCH METHODS}

The data used in this study is secondary data, namely OK Stocks, IDX Statistics, IDX Factbook, closing stock prices at the end of the year and the number of shares outstanding at the end of the year. Annual financial statements and notes to financial statements. The population in this study were companies registered in BUMN in $2016-$ 2019. Sampling was carried out using the purposive sampling method and had certain criteria. The criteria used are as follows: 1). BUMN companies that are listed on the Indonesia Stock Exchange (IDX) and publicly report their financial statements and publish financial reports consistently and completely from 2016 - 2019. 2). Companies that publish complete financial reports and data. 3) Does not have negative leverage.

The data used in this study is secondary data in the form of the company's annual financial statements obtained from the IDX website page, especially data from 2016 2019. The type of data collection used is time series. Descriptive statistics are statistical methods used to describe the data that has been collected. Descriptive statistics provide an overview or description of a data seen from the average value (mean), standard deviation, maximum, minimum. The information in these descriptive statistics will be presented in a concise, neat, and can provide core information from the existing data set. Data information that can be obtained from these descriptive statistics includes the size of the data concentration, the size of the data spread, and the tendency of a data set. There are four kinds of classical assumption tests that will be used to test the data in this study (Heteroscedasticity Test, Normality Test, Multiculinearity). 


\section{Gracela Mayaniputri Tamur}

Testing the hypothesis of the effect of institutional ownership structure variables, Debt Covenant and Growth Opportunities on accounting conservatism (H1, H2, H3) using multiple regression analysis tools.

\section{RESULTS AND DISCUSSION}

\section{A. Descriptive Statistical Analysis}

This study uses 3 independent variables, namely Institutional Ownership, Debt Covenant, Growth Opportunity. While the dependent variable in this study is accounting conservatism. Descriptive statistics in this study aim to provide an overview of the relevant information contained in the study. Descriptive statistical testing using SPSS version 20 program with the following results:

Table 1. Descriptive Statistical Analysis Test Results

\begin{tabular}{|c|c|c|c|c|c|c|}
\hline \multicolumn{7}{|c|}{ Descriptive Statistics } \\
\hline & & $\overline{\mathrm{N}}$ & Minimum & Maximum & Mean & Std. Deviation \\
\hline Con & & 4 & 1025 & 9816 & 4 & 2792.900 \\
\hline & 4 & & & & 476.11 & \\
\hline $\mathbf{X 1}$ & & 4 & 0 & 9 & .9 & 1.930 \\
\hline $\mathbf{X} 2$ & 4 & 4 & 0 & 6 & $\begin{array}{ll}7 & \\
02 & 3 .\end{array}$ & 1.907 \\
\hline $\mathbf{X} 3$ & 4 & 4 & -10 & 254 & $7.35^{2}$ & 58.006 \\
\hline $\begin{array}{r}\text { Valid } \\
\mathbf{N} \text { (listwise) }\end{array}$ & 4 & 4 & & & & \\
\hline
\end{tabular}

\section{B. Classical Assumption Test Results \\ Normality test}

Normality test aims to test whether the processed data is normally distributed or not. The normality test of the data was carried out using the P-P plot test with the help of the SPP version 20 program. The results of the data normality test are as follows:

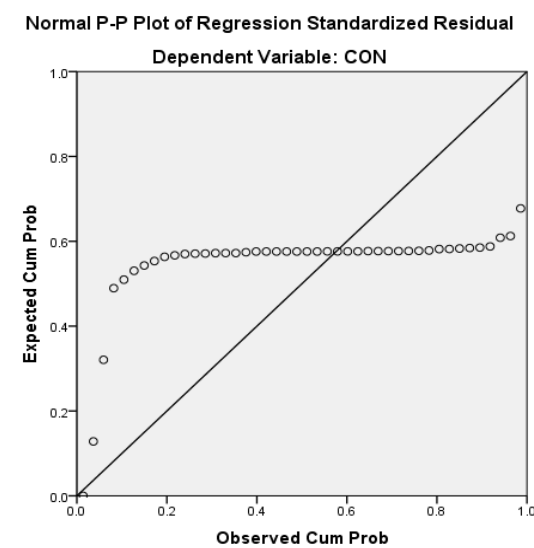

Figure 1 Normality test using p-p plot method

Based on Figure 2 above, for the normality test using the p-p plot method, the results obtained are not significant from the normality test, the data spreads away from 
the diagonal line does not follow the direction of the diagonal line does not show a normal distribution pattern, then the regression model does not meet the normality requirements of this study. A good regression model is a regression model that has a normal or close to normal data distribution.

\section{Multicollinearity Test}

Multicollinearity test aims to test whether the regression model found a correlation between the independent variables/independent variables. The multicollinearity test of the data in this research uses SSPS Version 20. The results of the multicollinearity test of the research data are as follows:

Table 2 Multicollinearity test

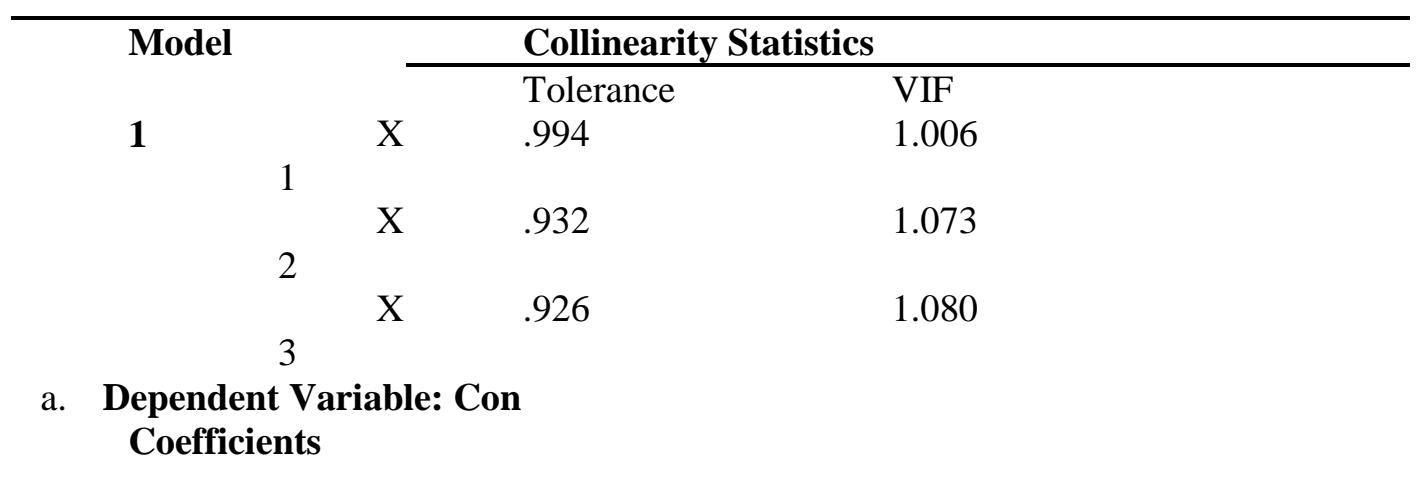

Based on table 2, it can be seen that the research conducted is free from the problem of multicollinearity. This is shown by evidence that the institutional ownership variable $(\mathrm{X} 1)$ produces a VIF value $=1.006$ Tolerance 0.994 while the debt covenant variable $(\mathrm{X} 2)$ produces a VIF value $=1.073$ Tolerance 0.932 and the growth opportunity variable $(\mathrm{X} 3)$ produces a VIF value $=1.080$ Tolerance 0.926 where This value indicates that the regression model is free from multicollinearity symptoms because the VIF $<10$ and the Tolerance value> 0.1 .

\section{Heteroscedasticity test}

Heteroscedasticity test aims to test whether the regression model found a correlation between independent variables or not. The results of the heteroscedasticity test are as follows:

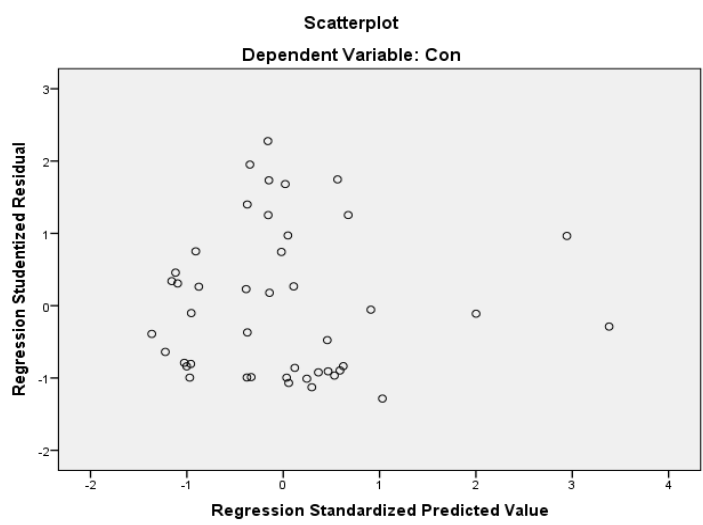

Figure 2 Hetetoscedasticity Test Results

Based on Figure 2, it can be seen that in this study it was free from heteroscedasticity. This is in accordance with the basis for decision making. If there is no 


\section{Gracela Mayaniputri Tamur}

clear pattern, and the points are spread above and below the number 0 on the y-axis, it indicates that there is no heteroscedasticity problem.

\section{Multiple Regression Test Analysis Results \\ Coefficient of Determination Test (R2)}

The coefficient of determination aims to find out what percentage of the influence given by variable $\mathrm{X}$ simultaneously (simultaneously) to variable $\mathrm{Y}$. The following are the results of data processing seen in the following table

Table 3 Coefficient of Determination Test Results

\begin{tabular}{|c|c|c|c|c|}
\hline \multicolumn{5}{|c|}{ Model Summary $^{\text {b }}$} \\
\hline Model & F R Square & $\begin{array}{l}\text { Adjusted } \quad \mathrm{R} \\
\text { Square }\end{array}$ & $\begin{array}{l}\text { Std. Error of the } \\
\text { Estimate }\end{array}$ & Durbin-Watson \\
\hline & $\begin{array}{c}286^{\mathrm{a}} \\
\text { Predictors: (Constan } \\
\text { Dependent Variable: }\end{array}$ & $\begin{array}{r}.131 \\
\mathbf{X 3}, \mathbf{X 1}, \mathbf{X 2} \\
\text { on }\end{array}$ & 2775.151 & 1.995 \\
\hline
\end{tabular}

Based on table 3, it can be seen that the determinant coefficient (Adjusted $\mathrm{R}$ Square) is 0.131 or $13.1 \%$. This shows that the perception of institutional ownership, debt covenants, growth opportunity, on accounting conservatism is $13.1 \%$ while the other $86.9 \%$ are factors not examined in this study.

Simultaneous Effect Test (F Test)

The $\mathrm{F}$ test aims to determine whether or not there is a simultaneous (simultaneous) effect given by the independent variable $(\mathrm{X})$ on the dependent variable (Y). The basis for decision making in the simultaneous test is the calculated $\mathrm{F}$ value $>\mathrm{F}$ table. The following are the results of data processing using SPSS version 20 with the following results:

Table 4 Simultaneous Effect Test Results (F-Test)

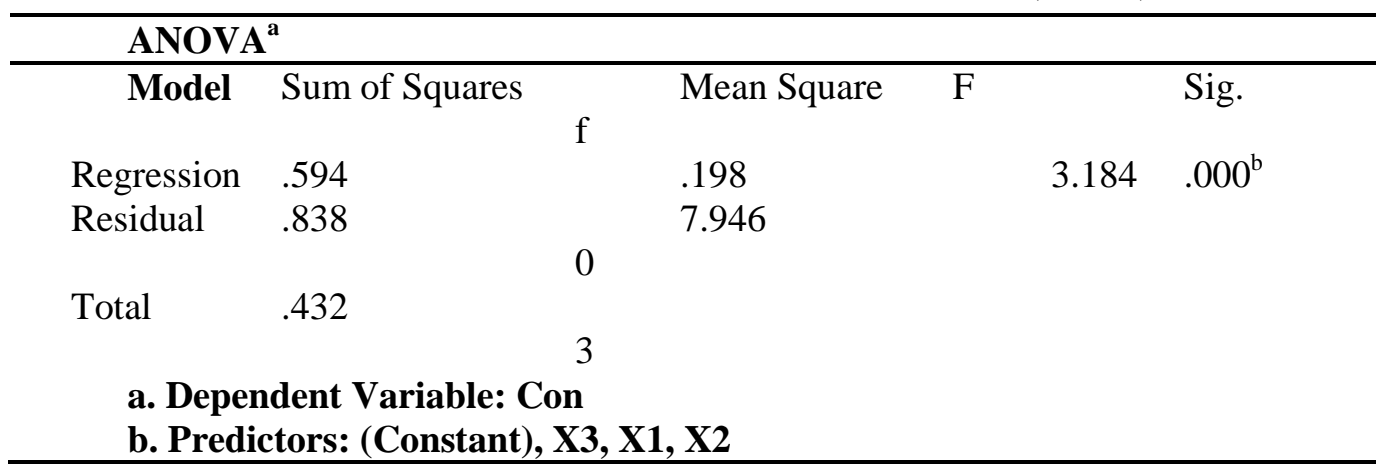

Based on table 4, the results show that the independent variable has an effect of 0.000 , which is smaller than 0.05 . The calculated $F$ value in this study is 3.184 which is above the $\mathrm{F}$ table which is 2.84 . Thus, it can be concluded that institutional ownership, debt covenants, growth opportunity simultaneously (simultaneously) against accounting conservatism. 


\section{T-test}

The t-test was used to test the significance of the relationship between variables $\mathrm{X}$ and $\mathrm{Y}$, whether accounting conservatism (X1), institutional ownership (X2), debt covenants (X3) growth opportunity (Y). The results of the $t$ test are as follows:

Table 5 Partial Test Results (t Test)

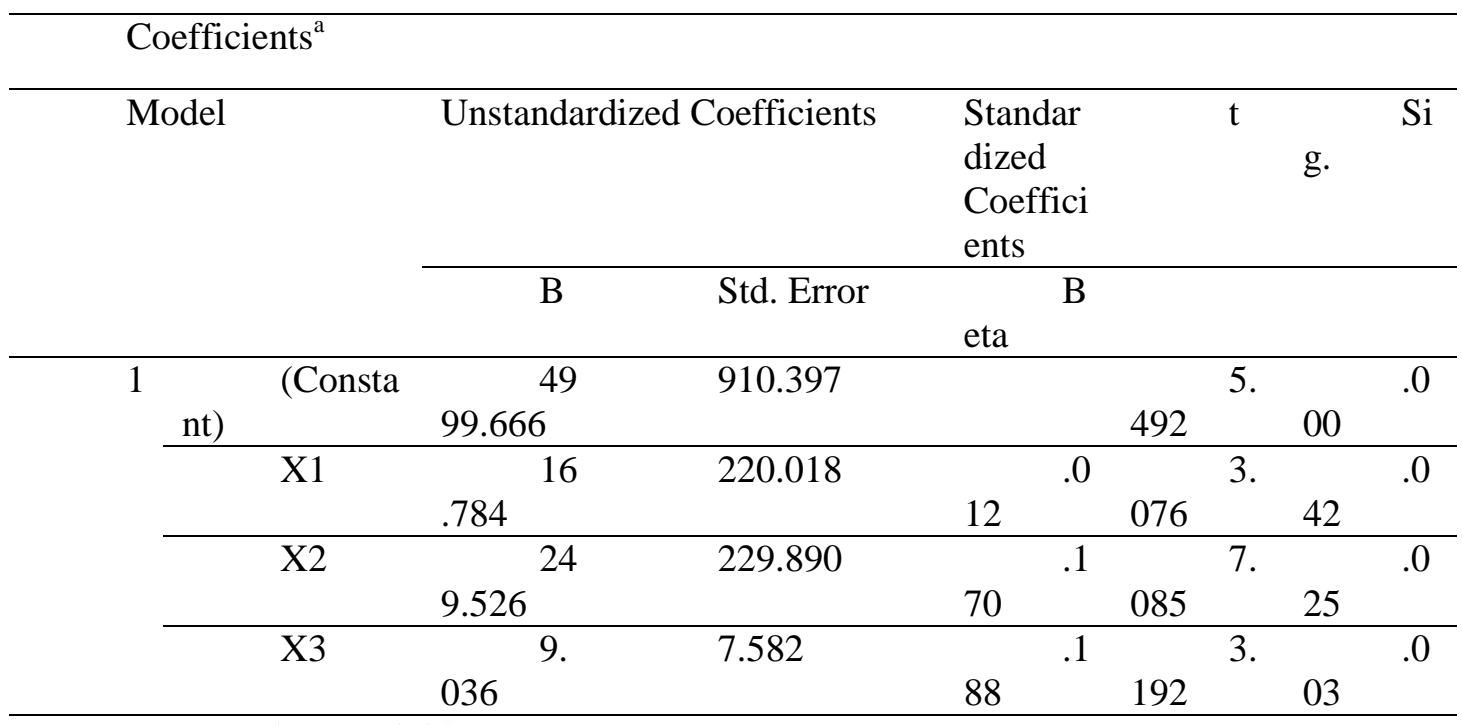

a. Dependent Variable: Con

D. Discussion

Table 6 Variable Calculation Results

\begin{tabular}{cllll}
\hline \multicolumn{1}{c}{ Description } & T & Sig & Decision \\
\hline H1 & $\begin{array}{l}\text { Institutional ownership } \\
\text { structure has a significant } \\
\text { positive effect on } \\
\text { accounting conservatism. }\end{array}$ & 5.492 & 0.000 & Accepted \\
H2 $\begin{array}{l}\text { Debt Covenant has a } \\
\text { significant positive effect } \\
\text { on accounting conservatism } \\
\text { Growth Opportunity has a } \\
\text { significant positive effect } \\
\text { on accounting conservatism }\end{array}$ & 3.076 & 0.042 & Accepted \\
\hline
\end{tabular}

Based on the calculation results presented in table 6, it can be explained as follows:

\section{1) The effect of institutional ownership structure on accounting conservatism.}

Based on the results of calculations in table 6, the institutional ownership structure variable has a t table value of 5.492 with a significance value of 0.042 at a significance level of $=5 \%$. Because the significance value is $0.42<0.05$, this indicates that the level of institutional ownership structure affects the application of accounting conservatism so that $\mathrm{H} 1$ is accepted. This means that institutional ownership structure variables are predictors that can affect companies in applying the principles of accounting conservatism. In other words, the proportion of institutional ownership structure in BUMN companies listed on IDX in 2016-2019 is still relatively low. This shows that 


\section{Gracela Mayaniputri Tamur}

most of the company's management in the sample companies have a larger proportion of shares in the companies they manage. Thus, the low institutional ownership structure in a company indicates that institutional investors are suspected of not being optimal in monitoring management behavior and performance.

In addition, institutional investors are suspected of not having a sense of ownership of the company and only focusing on high returns on their investments in the form of high dividends and capital gains without taking into account the company's reported profits. This could be the cause of institutional ownership structure not having a significant effect on accounting conservatism. The results of this study are consistent with research conducted by (Savitri, 2018) which states that institutional ownership structure has no significant effect on accounting conservatism.

\section{2) Effect of Debt Covenant on Accounting Conservatism}

Based on the results of the calculations in the table, the Debt covenant variable has a table value of 3,076 with a significance value of 0.042 . the significance of the Debt covenant variable is smaller than the significance level of $=5 \%$. This shows that the debt covenant has a positive direction and has a significant effect on accounting conservatism. The results of this study indicate that debt covenants have a significant positive effect on accounting conservatism or $\mathrm{H} 2$ is accepted. This is because if the Debt Covenant is not approaching his retirement period, the Debt Covenant will tend to be careful in making decisions which will produce quality profits. In other words, debt covenants that are not close to retirement will tend to apply the principles of accounting conservatism. According to Almilia (2018), the profit value presented in financial statements prepared by applying the principle of conservatism will produce quality profits because it shows a minimum profit (understatement) or profit whose value is not exaggerated.

In their research, Shimin and Serene (2017) state that debt covenants who are nearing retirement from their positions will increase profits to become overstatements by increasing income so that the bonuses they get will be high. Debt covenants will also increase revenue and reduce costs so that the profit generated is high (overstated) so that their performance will be assessed as good by the company and not dismissed from their executive positions. approaching retirement age will tend to manipulate earnings to improve short-term performance before they are dismissed from the company.

\section{3) The effect of growth opportunity on accounting conservatism}

Based on the results of the calculations in the table of institutional ownership structure variables, the $t$ table value is 0.003 with a significance value of 0.025 . the significance of the growth opportunity variable is smaller than the significance level of $=$ $5 \%$. This shows the growth opportunity that high and low affect the application of accounting conservatism so that $\mathrm{H} 3$ is accepted.

This means that the growth opportunity variable is a predictor that can affect companies in applying the principles of accounting conservatism. In other words, the amount of debt does not guarantee companies to be more careful in making decisions. With the acceptance of $\mathrm{H} 3$, this shows that the creditor supervises the operation of the company's operations and accounting methods so that the creditor provides leeway for the manager in his debt agreement. In addition, creditors only focus on management's ability to pay loan principal and loan interest smoothly without taking into account the company's reported profits so that the high and low level of growth opportunity does not affect the company in implementing accounting conservatism. 


\section{CONCLUSION}

Based on the results of data analysis using multiple linear regression analysis consisting of the F test, $t$ test, and the coefficient of determination (R2) test as well as the discussion that has been carried out, the researchers can draw the following conclusions: 1) Institutional ownership structure affects accounting conservatism, 2) Debt covenants have an effect on accounting conservatism, 3) Gross opportunity has a significant positive effect on accounting conservatism.

\section{REFERENCES}

Ardiansyah, Misnen. (2014). Bayang-bayang teori keagenan pada produk pembiayaan perbankan syariah. Ijtihad: Jurnal Wacana Hukum Islam Dan Kemanusiaan, 14(2), 251-269.

Damayanti, Putu Eka, Edy Sujana, S. E., Werastuti, Desak Nyoman Sri, \& SE, Ak. (2015). Pengaruh Karakteristik Informasi Sistem Akuntansi Manajemen (SAM), Desentralisasi, dan Ketidakpastian Lingkungan Terhadap Kinerja Manajerial (Studi Empiris Pada Hotel Se-Kabupaten Buleleng). JIMAT (Jurnal Ilmiah Mahasiswa Akuntansi) Undiksha, 3(1).

Fadillah, Adil Ridlo. (2017). Analisis pengaruh dewan komisaris independen, kepemilikan manajerial dan kepemilikan institusional terhadap kinerja perusahaan yang terdaftar di LQ45. Jurnal Akuntansi, 12(1), 37-52.

Limantauw, Shirly. (2012). Pengaruh karakteristik dewan komisaris sebagai mekanisme good Corporate govenance terhadap tingkat konservatisme akuntansi Pada perusahaan manufaktur yang terdaftar di BEI. Jurnal Ilmiah Mahasiswa Akuntansi, $1(1), 48-52$.

Mahariana, IDGP, \& Ramantha, I. Wayan. (2014). Pengaruh kepemilikan manajerial dan kepemilikan institusional terhadap manajemen laba. E-Jurnal Akuntansi Universitas Udayana, 7(3), 688-699.

Ngadiman, Ngadiman, \& Puspitasari, Christiany. (2017). Pengaruh Leverage, Kepemilikan Institusional, Dan Ukuran Perusahaan Terhadap Penghindaran Pajak (Tax Avoidance) Pada Perusahaan Sektor Manufaktur Yang Terdaftar Di Bursa Efek Indonesia 2010-2012. Jurnal Akuntansi, 18(3), 408-421.

Oktomegah, Calvin. (2012). Faktor-faktor yang mempengaruhi penerapan konservatisme pada perusahaan manufaktur di BEI. Jurnal Ilmiah Mahasiswa Akuntansi, 1(1), 3642.

Pratiwi, Rafika, \& Yulianto, Arief. (2016). Pengaruh Struktur Kepemilikan dan Komisaris Independen terhadap Biaya Keagenan Perusahaan yang Masuk dalam Indonesia Most Trusted Companies. Management Analysis Journal, 5(3).

Putri, Vidiyanna Rizal, \& Putra, Bella Irwasyah. (2017). Pengaruh Leverage, Profitability, Ukuran Perusahaan Dan Proporsi Kepemilikan Institusional Terhadap Tax Avoidance. Jurnal Manajemen Dayasaing, 19(1), 1-11.

Ramadona, Aulia, Tanjung, Amries Rusli, \& Rusli, Rusli. (2016). Pengaruh Struktur Kepemilikan Manajerial, Struktur Kepemilikan Institusional, Ukuran Perusahaan dan Leverage terhadap Konservatisme Akuntansi (Studi pada Perusahaan Makanan dan Minuman yang Terdaftar di Bursa Efek Indonesia Tahun 2011-2014). Riau University. 
Rebecca, Yulisa, \& Siregar, Sylvia Veronica. (2012). Pengaruh corporate governance index, kepemilikan keluarga, dan kepemilikan institusional terhadap biaya ekuitas dan biaya utang: studi empiris pada perusahaan manufaktur yang terdaftar di BEI. Simposium Nasional Akuntansi XV, 1-28.

Rizkianti, Wardani. (2017). Akta Otentik Rapat Umum Pemegang Saham (RUPS) Melalui Media Telekonferensi (Mekanisme Pembuatan dan Kekuatan Pembuktiannya). Jurnal Yuridis, 3(1), 83-98.

Savitri, Enni. (2018). Pengaruh struktur kepemilikan institusional, debt covenant dan growth opportunities terhadap konservatisme akuntansi. Jurnal Al-Iqtishad, 12(1), 39-54.

Sembiring, Carolyn Lukita. (2017). Manajemen Laba dan Pengungkapan Tanggung Jawab Sosial Perusahaan Dengan Komisaris Independen dan Kepemilikan Institusional Sebagai Variabel Pemoderasi. Berkala Akuntansi Dan Keuangan Indonesia, 2(1).

Siregar, Eliana. (2017). Hakikat Manusia (Tela'ah Istilah Manusia Versi Al-Qur'an dalam Perspektif Filsafat Pendidikan Islam). Majalah Ilmu Pengetahuan Dan Pemikiran Keagamaan Tajdid, 20(2), 48-67.

Susanto, Yulius Kurnia. (2011). Kepemilikan saham, kebijakan dividen, karakteristik perusahaan, risiko sistimatik, set peluang investasi dan kebijakan hutang. Jurnal Bisnis Dan Akuntansi, 13(3), 195-210.

Syadeli, Moh. (2013). Struktur kepemilikan, profitabilitas dan ukuran perusahaan terhadap kebijakan hutang perusahaan pemanufakturan di Bursa Efek Indonesia. Jurnal Manajemen Dan Akuntansi, 2(2).

Yendrawati, Reni. (2015). Pengaruh dewan komisaris independen, komite audit, kepemilikan manajerial, dan kepemilikan institusional terhadap manajemen laba. Jurnal Entrepreneur Dan Entrepreneurship, 4(1, 2), 33-40.

Zaudah Cyly Arrum Dalu, Zaudah, \& Mojibur Rohman, Mojib. (2019). Pengembangan elearning sebagai media pembelajaran simulasi dan komunikasi digital bagi siswa SMK. Jurnal Pendidikan Teknik Elektro, 4(1), 25-33. 